\title{
METAKOGNISI CALON GURU BERGAYA KOGNITIF REFLEKTIF DAN KOGNITIF IMPULSIF DALAM MEMECAHKAN MASALAH MATEMATIKA
}

\author{
Binur Panjaitan \\ FKIP Universitas HKBP Nommensen Medan \\ email: panjaitan_binur@yahoo.com
}

\begin{abstract}
Abstrak: Penelitian ini bertujuan untuk mendeskripsikan proses metakognisi mahasiswa calon guru dalam menyelesaikan masalah matematika. Jenis penelitian ini adalah penelitian eksploratif dengan pendekatan kualitatif. Masalah matematika dalam penelitian ini terdiri atas masalah matematika formal dan masalah matematika kontekstual. Subjek penelitian ini adalah mahasiswa calon guru Program Studi Pendidikan Matematika Fakultas Keguruan dan Ilmu Pendidikan Universitas HKBP Nommensen yang bergaya kognitif reflektif dan yang bergaya kognitif impulsif. Teknik pengumpulan data dilakukan lewat wawancara mendalam untuk menggali hal-hal yang memengaruhi terjadinya proses metakognisi subjek. Untuk menentukan gaya kognitif reflektif-impulsif digunakan Matching Familiar Figure Test. Data yang sudah valid dianalisis dengan memperhatikan bagaimana proses metakognisi subjek terhadap permasalahan. Hasil penelitian menunjukkan bahwa proses metakognisi subjek yang bergaya kognitif reflektif berbeda dengan proses metakognisi subjek yang bergaya kognitif impulsif, baik dalam masalah matematika formal maupun matematika kontekstual.
\end{abstract}

\section{Kata kunci: metakognisi, pemecahan masalah, gaya kognitif}

\section{THE METACOGNITIONOF PROSPECTIVE TEACHERS WITH REFLECTIVE AND IMPULSIVE COGNITIVESTYLEIN SOLVING MATHEMATICAL PROBLEMS}

\begin{abstract}
The purpose of this research is to describe the metacognition process of college students,as prospective teachers, in solving mathematical problems, either formal and contextual problems. This research is explorative using qualitative approach. The subject of research was students ofthe Mathematics Department, Faculty of Teacher Training and Education Nommensen University who have either reflective or impulsive cognitive style. Depth interviewwas carried out to find outthe factors that affect the subjects' metacognition. Matching Familiar Figure Test was employed to figure out students' cognitive style of either reflective or impulsive type. The data were then analyzed by paying attention at the subjects' metacognition process in solving mathematical problems. The results show that the metacognition process of those with reflective cognitive style is different from those with impulsive cognitive style, either in formal or contextual mathematical problem.
\end{abstract}

Keywords: metacognition, problem solving, cognitive styles

\section{PENDAHULUAN}

Proses belajar matematika merupakan proses mental yang berkaitan dengan kegiatan berpikir dan bagaimana pengembangannya untuk memperoleh pengetahuan, keterampilan dan membentuk sikap. Manfaat tersebut diharapkan dapat diperoleh sebagai hasil dari proses pemecahan masalah. Melalui pemecahan masalah matematika, siswa diarahkan untuk mengembangkan kemampuannya antara lain membangun pengetahuan matematika yang baru, memecahkan masalah dalam berbagai konteks yang berkaitan dengan matematika, menerapkan berbagai strategi yang diperlukan, dan merefleksikan proses pemecahan masalah matematika (Pearson Learning Group, 2008).

Dalam pemecahan masalah, proses berpikir siswa merupakan hal yang perlu mendapat perhatian guru terutama untuk membantu siswa agar dapat mengembangkan kemampuannya memecahkan masalah baik dalam konteks dunia nyata maupun dalam konteks matematika. Hal ini sejalan dengan pendapat Lester (Gartman dan Freiberg, 1993) bahwa tujuan utama mengajarkan pemecahan masalah dalam matematika adalah tidak hanya untuk melengkapi siswa dengan 
sekumpulan keterampilan atau proses, tetapi lebih kepada memungkinkan siswa berpikir untuk dirinya sendiri.

Permasalahan yang sering terjadi bahwa ketika siswa dihadapkan pada masalah matematika, siswa tersebut tidak memikirkan bagaimana dirinya mampu menyelesaikannya. Berpikir untuk dirinya sendiri berkaitan dengan kesadaran siswa terhadap kemampuannya untuk mengembangkan berbagai cara yang mungkin ditempuh dalam memecahkan masalah. Proses menyadari dan mengatur berpikir siswa dikenal sebagai metakognisi, termasuk di dalamnya adalah berpikir tentang bagaimana siswa membuat pendekatan terhadap masalah, memilih strategi yang digunakan untuk menemukan pemecahan, dan bertanya kepada diri sendiri tentang masalah tersebut (Gartman dan Freiberg, 1993).

Langkah-langkah pemecahan masalah yang digunakan dalam penelitian ini adalah yang dikembangkan De Corte (2003) dan menyebutnya sebagai strategi metakognitif dalam pemecahan masalah. Langkah-langkah tersebut adalah sebagai berikut: (1) membangun representasi mental dari masalah (buat gambar, buat daftar, skema atau tabel, pisahkan antara data yang relevan dengan yang tidak, gunakan pengetahuan nyata); (2) membuat rencana memecahkan masalah (buat diagram alir, duga dan periksa, perhatikan pola, sederhanakan bilangannya); (3) melaksanakan rencana pemecahan; (4) menginterpretasikan hasil dan rumuskan jawaban; (5) evaluasi solusi.

Beberapa peneliti telah menunjukkan bahwa metakognisi berperan penting dalam pemecahan masalah serta dalam perolehan dan penerapan keterampilan belajar pada berbagai bidang penemuan (Flavell, 1979; Panaoura dan Philippou, 2005). Siswa yang mampu menyerap pelajaran matematika pada tingkatan paling tinggi dan memperoleh informasi tentang latihan dalam strategi metakognitif (yaitu perencanaan, pemantauan, dan evaluasi belajarnya sendiri) memiliki kemampuan lebih baik dalam mengatur belajarnya (Chamot, Dale, O’Malley dan Spanos, 1992). Pemecahan masalah yang efektif dapat diperoleh dengan memberi kesempatan kepada siswa untuk menerapkan strategi metakognitif ketika menyelesaikan soal (McLoughlin dan Hollingworth, 2003).

Dari uraian yang sudah dikemukakan di atas, dapat diketahui betapa pentingnya kemam-

Tabel 1. Aktivitas Metakognisi dalam Pemecahan Masalah Matematika

\begin{tabular}{|c|c|c|c|}
\hline No. & Merencanakan & Memantau & Refleksi \\
\hline 1 & Menentukan posisi awal & Mengontrol perhitungan & Refleksi pada konsep-konsep \\
\hline 2 & $\begin{array}{l}\text { Menetapkan urutan } \\
\text { penggunaan cara }\end{array}$ & $\begin{array}{l}\text { Mengontrol suatu } \\
\text { pemeriksaan (yang dianggap) } \\
\text { kesalahan (ketika } \\
\text { menghitung atau menulis } \\
\text { kembali) }\end{array}$ & $\begin{array}{l}\text { Kesadaran pada metode, } \\
\text { komentar pada suatu } \\
\text { (kemungkinan salah) } \\
\text { penerapan/ penggunaan cara } \\
\text { matematika }\end{array}$ \\
\hline 3. & $\begin{array}{l}\text { Menetapkan suatu urutan } \\
\text { hasil pertengahan } \\
\text { (intermediate result) yang } \\
\text { dapat dicapai }\end{array}$ & $\begin{array}{l}\text { Mengontrol terminologi/ } \\
\text { notasi }\end{array}$ & $\begin{array}{l}\text { Analisis terhadap struktur } \\
\text { dari suatu ungkapan/ } \\
\text { lambang matematika }\end{array}$ \\
\hline 4. & $\begin{array}{l}\text { Merencanakan suatu } \\
\text { representasi (rumus, grafik, } \\
\text { teks, dsb) untuk mendukung } \\
\text { pemahaman }\end{array}$ & Mengontrol argumentasi & $\begin{array}{l}\text { Analisis struktur } \\
\text { pengambilan keputusan }\end{array}$ \\
\hline 5. & $\begin{array}{l}\text { Merencanakan aktivitas } \\
\text { metakognitif }\end{array}$ & $\begin{array}{l}\text { Pengungkapan posisi: } \\
\text { menentukan kekurangan } \\
\text { pengertian }\end{array}$ & $\begin{array}{l}\text { Pilihan yang disengaja suatu } \\
\text { representasi (rumus, grafik, } \\
\text { istilah, teks, dsb) }\end{array}$ \\
\hline 6. & & $\begin{array}{l}\text { Pengungkapan posisi: } \\
\text { menentukan kekurangan } \\
\text { perencanaan }\end{array}$ & $\begin{array}{l}\text { Refleksi } \\
\text { pemeriksaan /evaluasi }\end{array}$ \\
\hline 7. & & $\begin{array}{l}\text { Memantau petunjuk pada } \\
\text { fakta dan tujuan }\end{array}$ & $\begin{array}{l}\text { Mengenali interaksi dari } \\
\text { representasi dan gagasan } \\
\text { (yang salah) sebagai suatu } \\
\text { tema control }\end{array}$ \\
\hline 8. & & Memantau-diri sendiri & \\
\hline
\end{tabular}


puan metakognisi dimiliki oleh siswa pada semua tingkat pendidikan. Berkaitan dengan itu, penulis memandang perlu untuk mengetahui metakognisi mahasiswa calon guru dalam memecahkan masalah matematika, baik masalah matematika formal maupun kontekstual. Masalah matematika formal adalah masalah matematika yang disajikan dalam bentuk kalimat matematika dengan menggunakan simbol-simbol atau variabel-variabel tertentu, dan masalah matematika kontekstual adalah masalah matematika yang berkaitan dengan konteks.

Cohors-Fresenborg \& Kaune (2007) mengelompokkan aktivitas metakognisi dalam memecahkan masalah matematika terdiri atas (1) perencanaan (planning), (2) pemantauan (monitoring), dan (3) refleksi (reflection), lebih rinci disajikan pada Tabel 1.

Bell, Costello dan Kuchemann (1983) mengatakan situasi belajar yang paling efektif tidak sama bagi siswa. Perbedaan itu antara lain adalah bergantung pada faktor intelektual, emosional, kepribadian, dan kemungkinan jenis kelamin dan latar budaya. Perbedaan individual yang ada di antara siswa perlu diperhatikan untuk membantu proses pembelajaran yang lebih efektif. Salah satu perbedaan individual antara sesama siswa yang telah menjadi perhatian para psikolog adalah gaya kognitif. Gaya kognitif adalah cara yang konsisten atau kecenderungan seseorang dalam menggunakan kognitifnya (Kozhevnikov, 2007).

Kagan (Quiroga, Hernandez, Rubio, Shih, dan Santacreu, 2007) mengelompokkan gaya kognitif siswa yang disebut dengan gaya kognitif impulsif dan reflektif. Siswa yang bergaya kognitif reflektif memiliki karakteristik lambat dalam menyelesaikan masalah tetapi cermat/teliti, sehingga jawaban cenderung betul. Siswa yang bergaya kognitif impulsif memiliki karakteristik cepat menyelesaikan masalah tetapi kurang cermat/teliti sehingga jawaban cenderung salah.

Beberapa hasil penelitian telah menunjukkan indikasi bahwa hasil belajar siswa reflektif berbeda dengan siswa impulsif. Radatz (Bell, Costello dan Kuchemann, 1983) meneliti hubungan gaya kognitif impulsif-reflektif siswa dengan gaya kognitif impulsif-reflektif guru. Hasil penelitian itu menyatakan bahwa siswa impulsif cenderung lebih baik prestasinya jika diajar oleh guru impulsif, dan siswa reflektif cenderung lebih baik prestasinya jika diajar oleh guru reflektif.
Navarro, Aguilar dan Alcalde (1999) menyatakan bahwadalam meningkatkan prestasi aritmetika,siswa impulsif memerlukan bantuan pihak lain, sementara siswa reflektif kurang membutuhkan bantuan pihak lain.

Hasil penelitian Swartz dan Parkins(Warli, 2010), siswa impulsif memiliki pola pikir kurang efektif, sedangkan siswa reflektif memiliki pola pikir yang efektif karena dalam melakukan kognisinya selalu menuntut kesabaran dan ketelitian. Hasil penelitian Warli (2010), kreativitas siswa reflektif berbeda dengan kreativitas siswa impulsif dalam memecahkan masalah geometri. Kreativitas siswa reflektif relatif tinggi sementara siswa impulsif cenderung sangat rendah. Kreativitas mempunyai arah ke produk pemikiran yang baru dan fleksibilitas. Demikian juga dengan metakognisi juga mengarah ke produk pemikiran yang baru. Fleksibilitas juga dibutuhkan pada strategi metakognitif, yaitu siswa dalam menyelesaikan masalah diharapkan dapat mempunyai metode penyelesaian yang berbeda dari yang pernah diperoleh sebelumnya, sehingga ada dugaan metakognisi berhubungan dengan gaya kognitif impulsif-reflektif.

Hasil penelitian Bauersfeld (Bell, Costello dan Kuchemann, 1983) menunjukkan bahwa siswa yang bergaya kognitif reflektif lebih baik prestasinya dalam aritmetika dibandingkan dengan siswa impulsif.

Secara eksplisit hasil penelitian tentang gaya kognitif impulsif-reflektif belum ada yang menunjukkan bagaimana hubungannya dengan metakognitif, sehingga perlu diselidiki bagaimana siswa reflektif maupun siswa impulsif dalam memecahkan masalah matematika formal maupun matematika kontekstual.

\section{METODE}

Jenis penelitian ini adalah penelitian eksploratif dengan pendekatan kualitatif. Dikatakan penelitian eksploratif karena peneliti ingin menggali secara mendalam tentang hal-hal yang mempengaruhi terjadinya proses metakognisi subjek. Penelitian dengan pendekatan kualitatif adalah penelitian yang prosedur penelitiannya menghasilkan data deskriptif berupa kata-kata tertulis atau lisan dari subjek yang diamati. Penelitian ini mengungkap terjadinya proses metakognisi mahasiswa calon guru dalam memecahkan masalah matematika. 
Subjek penelitian ini adalah mahasiswa calon guru Program Studi Pendidikan Matematika Fakultas Keguruan dan Ilmu Pendidikan Universitas HKBP Nommensen yang bergaya kognitif reflektif dan yang bergaya kognitif impulsif.

Instrumen dalam penelitian ini terdiri dari instrumen utama dan instrumenbantu. Instrumen utama adalah peneliti sendiri, sehingga pada saat pengumpulan data di lapangan, peneliti berperan serta selama proses penelitian dan mengikuti kegiatan subjek penelitian yang berhubungan dengan pengumpulan data melalui wawancara. Selain peneliti sendiri sebagai instrumen utama, digunakan lembar tugas sebagai instrumen bantu. Sebelum wawancara dilakukan, mahasiswa diberi lembar tugas atau soal matematika formal dan soal matematika kontekstual. Soal matematika formal seperti: "Tentukan turunan dari fungsi $y=4 x^{3}-18 x^{2}+15 x-20$. Fungsi tersebut akan mencapai nilai maksimum bila nilai $x=\ldots$ " dan soal matematika kontekstual sebagai berikut: "Seorang petani tambak di Parapat akan memanen ikan mujahir dari tambak miliknya untuk dijual ke pasar. Dengan maksud untuk menjamin kualitas ikannya sekaligus menghemat biaya, maka petani tersebut memilih untuk tidak menggunakan bahan pengawet apapun. Agar ikan yang dipanennya tetap segar ketika sampai pada konsumen, maka ia harus sudah menjualnya setelah $t$ jam dari saat panen. Daya tahan ikan mujahir agar tetap segar dapat dinyatakan sebagai bilangan tak negatif yang sama dengan $15 \mathrm{t}^{2}-\mathrm{t}^{3}$. Tentukan waktu maksimum yang diperlukan oleh petani tambak tersebut agar ikannya tetap segar pada saat dijual".

Agar instrumen lembar soal matematika dapat berfungsi secara maksimal maka terlebih dahulu diawali dengan validasi oleh tenaga ahli, yang terdiri dari 2 orang ahli matematika, 2 orang ahli pendidikan matematika, dan 1 orang mahasiswa. Validasi diarahkan kepada kesesuaian instrumen lembar tugas dengan permasalahan, konteks matematika, dan konteks bahasa matematika yang digunakan.

Untuk mengukur gaya kognitif reflektifimpulsif digunakan Matching Familiar Figure Test (MFFT). Kerja tes MFFT adalah sebagai berikut: diberikan satu gambar standar, kemudian gambar standar itu dicari kembali di dalam enam buah gambar yang mirip yang diberikan sekaligus (Kagan, Rosman, Day, Albert, dan Philips (Kozhevnikov, 2007)). Variabel yang diamati pada MFFT ini adalah variabel waktu yang di- gunakan merespons tes dan variabel akurasi atau banyaknya kesalahan. Jika waktu yang digunakan kurang dari median, maka disebut penggunaan waktu sedikit, dan jika lebih dari median disebut penggunaan waktu lama. Demikian juga menentukan frekuensi banyaknya jawaban salah dan jawaban benar menggunakan median dari frekuensi menjawab benar (Quoriga, Hernandez, Rubio, Shih, dan Satracreu, 2007).

Dalam melakukan wawancara digunakan pedoman wawancara atau daftar pertanyaan sebagai pemandu awal. Namun demikian pedoman atau daftar pertanyaan ini tidak baku, artinya dapat berubah sesuai dengan situasi dan kondisi pada saat wawancara.

Untuk memperoleh gambaran tentang proses metakognisi, dilakukan langkah-langkah sebagai berikut: (1) mahasiswa diberi tugas untuk menyelesaikan soal dengan mengatakan sesuai dengan apa yang dia pikirkan, (2) peneliti meneliti hasil pekerjaan mahasiswa, (3) peneliti memberikan pertanyaan berkaitan dengan jawaban yang diberikan oleh mahasiswa melalui wawancara. Selanjutnya hasil data yang tertulis dan verbal (dari wawancara) dikaji kekonsistensinya. Apabila ada data yang tidak konsisten, harus dilakukan wawancara kembali. Data yang diperoleh pada saat wawancara direkam menggunakan tape recorder dan handycam. Berdasarkan hasil rekaman dari video dan hasil pekerjaan tertulis bagianbagian yang belum dapat dimengerti,peneliti dapat menunjukkan kepada subjek dan mendiskusikan setelah menyelesaikan semua soal.

Data yang sudah valid dianalisis dengan memperhatikan beberapa hal, misalnya, bagaimana proses metakognisi subjek terhadap permasalahan; konsep, operasi atau rumus/sifat apa yang digunakan dalam menyelesaikan masalah.

Data wawancara tentang proses metakognisi subjek ketika memecahkan masalah dianalisis pada setiap langkah sebagai berikut. Pada langkah membangun representasi mental dari masalah, bagaimana subjek melakukan planning, monitoring dan refleksi, pada langkah membuat rencana pemecahan masalah, bagaimana subjek melakukan planning, monitoring dan refleksi, pada langkah melaksanakan rencana pemecahan, bagaimana subjek melakukan planning, monitoring dan refleksi, dan pada langkah menginterpretasikan hasil dan rumusan jawaban, bagaimana subjek melakukan planning, monitoring dan refleksi, serta pada langkah evaluasi solusi bagaimana 
subjek melakukan planning, monitoring dan refleksi.

\section{HASIL DAN PEMBAHASAN}

Pada bagian ini disajikan hasil penelitianterhadap subjek penelitian dengan metode think aloud dikombinasikan dengan wawancara selama proses pemecahan masalah. Subjek berasal dari kelompok bergaya kognitif reflektif dan dari kelompok bergaya kognitif impulsif.

\section{Metakognisi Subjek Bergaya Kognitif Reflek- tif pada Pemecahan Masalah Matematika Formal}

Pada masalah matematika formal, subjek yang bergaya kognitif reflektif membangun representasi mental dari masalah dengan hanya membaca soal, dilanjutkan merencanakan pemecahan melalui aktivitas menentukan cara yang akan digunakan, kemudian melaksanakan rencana. Selanjutnya subjek kembali membuat rencana dengan melakukan refleksi terhadap syarat suatu fungsi bernilai maksimum dan merencanakan penggunaan cara untuk memfaktorkan.Ketika melaksanakan rencana pemfaktoran, subjek mengalami kesulitan.Pada langkah ini subjek melakukan beberapa usaha memfaktorkan dengan selalu memeriksa dengan akurat tahap demi tahap pemfaktoran yang dilakukan, walaupun menggunakan waktu yang lebih lama, dan ternyata subjek menyadari hasilnya yang salah. Hal ini sesuai dengan pendapat Kozhevnikov (2007), bahwa anak yang bergaya kognitif reflektif cenderung menyelesaikan masalah dengan menggunakan waktu lama dan penyelesaian cenderung benar dan akurat.

Ketika peneliti memberi pertanyaan, apakah fungsinya bisa disederhanakan, ternyata subjek dapat melakukan refleksi terhadap hasil pemfaktorannya yang salah, dan menyadari langkah yang semestinya dilakukan. Berikutnya subjek dapat melaksanakan rencana dan merumuskan jawaban dengan baik. Hal ini sesuai dengan pendapat Ancilotti (Rozencwajk dan Corroyer, 2005) yang menemukan bahwa anak yang reflektif cenderung memproses secara analitik.

Ketika memecahkan masalah, subjek sempat mengalami kesulitan, yang kemudian dapat diatasi setelah peneliti memberi satu pertanyaan. Masalah ini berhasil diselesaikan dengan kemampuan subjek untuk mengevaluasi solusi yang tadi sudah diketahuinya salah, melalui refleksi terhadap gagasannya yang salah. Selanjutnya subjek dapat melaksanakan rencana yang sudah dibuat sebelumnya. Rumusan jawaban yang tepat dapat dibuat berdasarkan pada interpretasi hasil perhitungan dengan hati-hati sebelum mengambil keputusan, dan kemudian subjek memantapkan keyakinannya. Hal ini sesuai dengan pendapat Rozencwajk dan Corroyer (2005), yang mengatakan bahwa anak yang reflektif memperhatikan semua kemungkinan pilihan dengan hati-hati sebelum mengambil keputusan.

Pada lembar kerja subjek secara tertulis, telah terungkap hasil pekerjaan yang memberi jawaban sesuai penjelasan lisan yang diberikannya, meski tidak merinci mengapa nilai maksimum $x=5 / 2$.

\section{Metakognisi Subjek Bergaya Kognitif Reflektif pada Pemecahan Masalah Matematika Kon- tekstual}

Pada pemecahan masalah matematika kontekstual, subjek bergaya kognitif reflektif mengawali dengan membaca soal yang langsung diikuti dengan refleksi yang menghubungkan objek dengan suatu konsep. Selanjutnya subjek membaca kembali dan menuliskan yang diketahui dan ditanyakan. Pembuatan rencana pemecahan diawali dengan refleksi terhadap metode yang akan digunakan yang selanjutnya merencanakan pemecahan dengan menggunakan metode yang sudah direfleksikannya. Langkah selanjutnya adalah melaksanakan rencana, melibatkan aktivitas metakognisi dengan memberikan penjelasan yang tepat dan mengontrol kecermatan perhitungan tahap demi tahap.

Proses berikutnya, subjek membuat rencana selanjutnya, yakni menentukan cara yang akan digunakan, diikuti dengan pelaksanaan rencana, yakni dengan aktivitas metakognisi memberikan alasan yang tepat dan pada akhirnya merumuskan jawaban berdasarkan interpretasi hasil perhitungan dan memberi penjelasan yang dikaitkan dengan pencapaian tujuan.

Peneliti kemudian memberi pertanyaan untuk melihat proses metakognisi, yang dijawab subjek melalui evaluasi solusi dengan memantau pencapaian tujuan, dan merefleksi kemampuan dan kelemahan subjek sendiri. Subjek kemudian menyadari ketidak-tahuannya terhadap alasan mengapa cara tersebut digunakan, tetapi subjek masih ingat bahwa bantuk soal semacam ini dapat diselesaikan menggunakan cara yang sudah pernah digunakannya. 
Pada jawaban tertulis, subjek juga tidak mengungkapkan hal-hal yang telah diungkapkannya secara lisan ke dalam bentuk tulisan pada lembar jawaban. Salah satu yang tidak jelas terungkap adalah rumusan jawaban. Keadaan ini tentu dapat berakibat pada tidak sampainya informasi yang seharusnya dikemukakan kepada orang lain yang akan menilai hasil kerjanya. Mengingat penilaian hasil belajar di sekolah selama ini banyak didasarkan pada hasil pekerjaan tertulis, maka hal ini tentu cukup merugikan subjek itu sendiri.

\section{Metakognisi Subjek Bergaya Kognitif Im- pulsif pada Pemecahan Masalah Matematika Formal}

Seperti halnya subjek bergaya kognitif reflektif, pada masalah matematika formal, subjek bergaya kognitif impulsif juga membangun representasi mental dari masalah langsung dengan membaca soal. Subjek kemudian merencanakan pemecahan yakni mencari turunan fungsi dengan aktivitas menentukan cara yang digunakan dan melaksanakan rencana tersebut dengan aktivitas metakognisinya. Selanjutnya subjek menentukan carauntuk mencari nilai maksimum, dan untuk itu subjek melakukan monitoring untuk memahami soal. Setelah melakukan monitoring, subjek kembali merencanakan pemfaktoran dan diikuti refleksi terhadap rencana yakni memperhatikan dampak cara yang digunakan, sehingga subjek dapat menentukan bahwa fungsi dapat lebih mudah difaktorkan bila dibagi 3 lebih dulu. Hasil refleksi ini mengarahkan subjek untuk memperbaharui cara yang digunakannya.

Pada tahap ini peneliti melihat kurang sempurnanya rencana dan pelaksanaanya khususnya berkaitan dengan fungsi yang difaktorkan, sehingga perlu memberi pertanyaan. Subjek menjawab pertanyaan peneliti melalui refleksi dengan melihat kemungkinan kesalahan terhadap solusi dan akhirnya dapat menyadarinya, tetapi tidak dapat memberikan alasan yang tepat dan hanya memberi argumentasi negatif, dan subjek memberikan argumentasi negatif tersebut dengan cara tergesa-gesa atau dengan waktu yang sangat singkat. Hal ini sesuai dengan pendapat Kozhevnikov (2007) bahwa anak yang bergaya kognitif impulsif cenderung menyelesaikan masalah dengan menggunakan waktu yang singkat tetapi penyelesaian cenderung salah dan tidak akurat.

Peneliti juga mengajukan beberapa pertanyaan untuk mengetahui metakognisi subjek pada langkah selanjutnya, dan subjek menjawab dengan melakukan refleksi pada evaluasi solusi, dan refleksi pada pemahaman masalah. Disamping itu subjek juga melakukan pemantauan solusi yang diperoleh dan kemudian merumuskan jawaban.

Berdasarkan hasil pekerjaan subjek secara tertulis, tampak bahwa penyajian hasil pemecahan masalah secara tertulis tidak menggambarkan hasil dengan baik. Salah satu kekurangan penyajian informasi dari pekerjaan tertulis tersebut adalah tidak jelasnya rumusan jawaban terhadap pertanyaan pada soal. Subjek sebenarnya telah berusaha untuk menunjukkan nilai $\mathrm{x}$ agar fungsinya mencapai nilai maksimum, namun setelah mencoba melakukan perhitungan, subjek mendapati kerumitan perhitungan, kemudian langsung menghentikan perhitungan dan membuat kesimpulan dengan yakin bahwa nilai maksimum dicapai pada $x=5 / 2$. Nampaknya subjek tidak sabar untuk memeriksa tahap demi tahap, sehingga langsung mengambil keputusan dengan cepat. Hal ini sesuai dengan pendapat Pencheva dan Papazpva (2006), yang mengatakan bahwa anak yang impulsif cenderung mengambil keputusan dengan cepat setelah memeriksa pilihan jawaban.

\section{Metakognisi Subjek Bergaya Kognitif Im- pulsif pada Pemecahan Masalah Matematika Kontekstual}

Pada masalah matematika kontekstual, subjek bergaya kognitif impulsifmulai dengan membaca soal dan menuliskan yang diketahui dan ditanyakan yang diikuti dengan memeriksa terminologi tentang waktu maksimum.Pada langkah berikutnya subjek merencanakan pemecahan dengan cara menentukan satu cara yang digunakan dan langsung melaksanakan pemecahan dengan cara tersebut. Langkah berikutnya subjek membuat rencana pemecahan lagi dengan menentukan cara yang digunakan dan diteruskan dengan melaksanakan pemecahan dengan menentukan hasilnya, tetapi hasil ini tidak tepat. Peneliti coba membangkitkan metakognisi subjek melalui satu pertanyaan yang diberikan. Hasilnya subjek melakukan refleksi dengan mengenali representasi yang salah, namun hanya sebagian, dan tidak mencakup secara keseluruhan representasi tersebut.

Selanjutnya subjek merencanakan pemecahan berikutnya dengan menentukan cara yang akan digunakan. Ketika peneliti menanyakan alasan mengapa menggunakan cara tersebut, subjek memberi argumentasi negatif. Refleksi yang 
dilakukan subjek untuk mengenali gagasan yang salah dilakukan sebagai jawaban atas pertanyaan peneliti, dilanjutkan dengan memeriksa kesesuaian tujuan yang hendak dicapai.

Berikutnya subjek merencanakan pemecahan selanjutnya dengan menentukan cara yang digunakan, tetapi nilai yang digunakannya adalah nilai yang tidak benar sehingga peneliti mencoba memberi pertanyaan untuk membangkitkan metakognisinya lagi. Hasilnya, subjek melakukan refleksi dengan memperhatikan terjadinya kesalahan dan memperhatikan struktur lambang matematika yang digunakan.Hasil ini membuat refleksi selanjutnya sebagai jawaban terhadap pertanyaan peneliti menjadi terarah sesuai yang diharapkan. Hal ini sesuai dengan pendapat Navarro, Aguilar, dan Alcalde (1999) bahwa untuk meningkatkan prestasi, siswa impulsif memerlukan bantuan pihak lain seperti pelatihan, sementara siswa reflektif kurang membutuhkan bantuan pihak lain dalam memecahkan masalah aritmetika. Pemantauan dilakukan subjek terhadap kesesuaian tujuan yang hendak dicapai.

Langkah selanjutnya subjek merencanakan kembali pemecahan masalah dengan menentukan cara yang akan digunakan, kemudian peneliti memberi pertanyaan lagi untuk melihat metakognisi yang dilakukannya, dan subjek menjawab dengan melakukan refleksi terhadap rencana tersebut dengan melihat dampak penerapaan cara yang digunakannya.

Selanjutnya subjek melaksanakan pemecahan sesuai rencana dan memperoleh hasil, tetapi hasil ini tidak dimengerti oleh subjek, dan menyimpulkannya sebagai hasil akhir meski sebenarnya tidak sesuai dengan tujuan. Hasil yang tidak sesuai ini menunjukkan bahwa subjek tidak berhasil memahami masalah dengan benar sehingga tidak tahu kapan tujuan dapat dicapai. Peneliti mencoba membangkitkan metakognisi subjek dengan memberi pertanyaan, subjek menjawab dengan serangkaian refleksi, dan pada akhirnya subjek mengenali representasi yang salah sehingga dapat merumuskan jawaban sesuai hasil perhitungan dengan benar. Untuk meyakinkan hasil yang diperolehnya, peneliti memberikan beberapa pertanyaan dan dijawab subjek dengan melakukan pemantauan pada argumentasinya dan subjek meyakini bahwa argumentasi yang diberikannya sudah tepat.

Hasil pekerjaan subjek secara tertulis menunjukkan beberapa perubahan berpikir yang dilakukan oleh subjek, yang tampak pada beberapa coretan atau penggantian pada lembar jawaban. Perubahan ini kemungkinan menjadi salah satu penyebab terjadinya kebingungan, termasuk pada saat merumuskan jawaban akhir.

\section{Perbandingan Proses Metakognisi Subjek Ber- gaya Kognitif Reflektif dengan Subjek Bergaya Kognitif Impulsif pada Masalah Matematika Formal}

Pada masalah matematika formal, subjek bergaya kognitif reflektif membangun representasi mental dari masalah langsung dengan satu aktivitas metakognisi yakni menentukan posisi awal melalui aktivitas membaca soal saja.Pada masalah matematika kontekstual, subjek membangun representasi mental dari masalah dengan melibatkan beberapa aktivitas metakognisi pada menentukan posisi awal. Aktivitas tersebut terdiri atas dua aktivitas merencanakan dan satu aktivitas refleksi. Kedudukan refleksi pada tahap pemahaman masalah ini kiranya cukup penting dalam membantu subjek untuk memudahkan langkah pemecahan masalah selanjutnya.

Pada langkah membuat rencana pemecahan masalah, subjek melakukannya dengan melibatkan aktivitas metakognisi ketika menentukan cara yang akan digunakan dan didukung refleksi untuk memperhatikan dampak penggunaan cara. Aktivitas metakognisi yang dilakukan oleh subjek pada tahap ini sangat mirip antara masalah matematika formal dengan masalah matematika kontekstual.

Pada langkah pelaksanaan rencana pemecahan, subjek melakukannya dengan melibatkan aktivitas metakognisi mengontrol kecermatan perhitungan. Pada tahap ini, tampak pula bahwa subjek melakukan aktivitas metakognisi yang mirip antara masalah formal dan masalah kontekstual.

Pada langkah perumusan jawaban, subjek melakukan aktivitas metakognisi yakni merumuskan jawaban melalui interpretasi hasil perhitungan pada masalah formal. Pada masalah kontekstual, subjek merumuskan jawaban melalui interpretasi hasil perhitungan, didukung alasan yang tepat dengan memperhatikan pencapaian tujuan.

Evaluasi solusi dilakukan pada kedua jenis masalah yang dipecahkan. Salah satu evaluasi solusi yang dilakukan adalah terhadap langkah melaksanakan rencana pemecahan, yakni melalui aktivitas metakognisi refleksi untuk mengenali 
gagasan yang salah khususnya ketika subjek tidak dapat melakukan pemfaktoran pada masalah formal. Sedangkan pada masalah kontekstual evaluasi solusi dilakukan dengan aktivitas metakognisi memantau pencapaian tujuan dan refleksi untuk memperhatikan kekuatan dan kelemahan diri subjek sendiri. Kedua aktivitas metakognisi ini dilakukan setelah subjek selesai merumuskan jawaban.

\section{Perbandingan Proses Metakognisi Subjek Ber- gaya Kognitif Reflektif dengan Subjek Bergaya Kognitif Impulsif pada Masalah Matematika Kontekstual}

Pada langkah membangun representasi mental dari masalah, subjek melakukan aktivitas metakognisi membaca soal sambil menuliskan yang diketahui dan ditanyakan. Pada langkah ini subjek tidak lagi melakukan aktivitas metakognisi lain. Pada jenis masalah formal, langkah ini cukup sukses bagi subjek, hingga dapat menyelesaikan masalah dengan benar, namun langkah seperti ini menjadi tidak memberikan hasil yang baik pada masalah kontekstual. Keadaan ini terbukti pada bagian akhir ketika merumuskan jawaban, subjek tidak tahu yang mana diantara hasil-hasil perhitungan yang diperolehnya dapat dijadikan sebagai jawaban terhadap pertanyaan. Dengan kata lain, subjek mengalami kesulitan pada saat menginterpretasikan hasil perhitungan sebagai akibat dari tidak memahami masalah dengan baik.

Pada langkah membuat rencana pemecahan, subjek terfokus pada penentuan cara yang akan digunakan, baik pada masalah formal maupun pada masalah kontekstual. Dari hasil wawancara yang dilakukan peneliti terhadap subjek, terlihat bahwa ternyata subjek tidak mengetahui alasan mengapa cara yang dipilihnya harus digunakan. Beberapa pertanyaan yang diajukan peneliti, dijawab oleh subjek dengan argumentasi yang tidak tepat, atau dalam tulisan ini penulis sebut sebagai argumentasi negatif.

Pada langkah pelaksanaan rencana,terlihat bahwa aktivitas metakognisi subjek pada masalah kontekstual cukup bervariasi dengan melibatkan perencanaan, monitoring dan refleksi, sedangkan pada masalah formal, aktivitas metakognisi subjek hanya meliputi perencanaan saja tanpa melakukan pemantauan dan refleksi.

Pada langkah interpretasi hasil dan rumuskan jawaban, subjek melakukan beberapa aktivitas metakognisi pada soal kontekstual baik perencanaan, pemantauan maupun refleksi. Namun tidak demikian dengan masalah formal. Pada masalah formal, aktivitas metakognisi pada langkah ini hanya berupa rumusan jawaban seperti hasil perhitungan saja.

Pada langkah evaluasi solusi, untuk bentuk masalah matematika kontekstual, subjek melibatkan aktivitas metakognisi cukup beragam. Pada bentuk masalah formal, evaluasi solusi dilakukan dalam bentuk refleksi dan memperhatikan cara kerja sendiri. Pada masalah kontekstual, evaluasi solusi melibatkan aktivitas metakognisi berupa pemantauan dan refleksi.

\section{SIMPULAN}

Berdasarkan hasil yang sudah diperoleh, dapat dibuat kesimpulan berikut.

Pada pemecahan masalah matematika formal, proses metakognisi subjek yang bergaya kognitif reflektif dan subjek yang bergaya kognitif impulsif, terlihat bahwa kurangnya variasi aktivitas metakognisi pada setiap langkah pemecahan. Variasi aktivitas metakognisi hanya terjadi pada langkah evaluasi solusi yang khususnya dilakukan subjek bergaya kognitif impulsif sebagai respon atas pertanyaan peneliti. Secara lebih detail disajikan berikut.

(1) Pada langkah membangun representasi mental dari masalah dilakukan oleh subjek bergaya kognitif reflektif dan subjek bergaya kognitif impulsif langsung dengan satu aktivitas metakognisi yakni melalui aktivitas membaca soal saja.

(2) Pada langkah membuat rencana pemecahan, subjek bergaya kognitif reflektif dan subjek bergaya kognitif impulsif melakukannya aktivitas metakognisi yakni menentukan cara yang akan digunakan dan didukung refleksi untuk memperhatikan dampak penggunaan cara yang dipilih. Namun demikian, ternyata subjek bergaya kognitif impulsif tidak mengetahui alasan mengapa cara yang dipilihnya harus digunakan.

(3) Pada langkah pelaksanaan rencana pemecahan, subjek bergaya kognitif reflektif melakukan aktivitas metakognisi yakni mengontrol kecermatan perhitungan dilakukan sebagai wujud kesadarannya dalam usaha mengatasi kesulitan, namun tidak demikian dengan subjek yang bergaya kognitif impulsif.

(4) Pada langkah interpretasi hasil dan merumuskan jawaban, subjek bergaya kognitif 
reflektif melakukan aktivitas metakognisi yakni merumuskan jawaban melalui interpretasi hasil perhitungan, sedangkan subjek bergaya kognitif impulsif melakukan aktivitas metakognisi hanya berupa rumusan jawaban se-perti hasil perhitungan saja.

(5) Pada langkah evaluasi solusi, subjek bergaya kognitif reflektif melakukan refleksi untuk mengenali gagasan yang salah, sedangkan subjek bergaya kognitif impulsif melakukan refleksi dengan memperhatikan cara kerjanya saja.

Pada masalah matematika kontekstual, proses metakognisi yang dilakukan subjek bergaya kognitif reflektif dan subjek bergaya kognitif impulsif menunjukkan adanya dinamika, dan cukup berbeda dengan pada masalah matematika formal. Secara umum, keragaman aktivitas metakognisi terjadi pada langkah membangun representasi mental dari masalah, langkah interpretasi hasil dan merumuskan jawaban, serta pada langkah evaluasi solusi. Secara detail dikemukakan sebagai berikut.

(1) Pada langkah membangun representasi mental dari masalah dilakukan dengan melibatkan beberapa aktivitas metakognisi. Subjek bergaya kognitif reflektif melakukan dua aktivitas merencanakan yang diselingi oleh satu aktivitas refleksi, sedangkan subjek bergaya kognitif impulsif melakukan satu aktivitas aktivitas metakognisi membaca soal sambil menuliskan yang diketahui dan ditanya serta melakukan kontrol dengan memeriksa terminologi yang digunakan. Pada langkah ini subjek bergaya kognitif impulsif tidak melakukan refleksi yang ternyata pada akhirnya memunculkan kebingungan.

(2) Pada langkah membuat rencana pemecahan, subjek bergaya kognitif reflektif melakukan aktivitas metakognisi yang mirip dengan pada masalah formal, yakni menentukan penggunaan cara dan melakukan refleksi memperhatikan dampak penggunaan cara. Subjek bergaya kognitif impulsif melakukan langkah ini dengan hanya terfokus pada penentuan cara yang akan digunakan, tetapi subjek tidak mengetahui alasan mengapa cara yang dipilihnya mesti digunakan.

(3) Pada langkah melaksanakan rencana pemecahan, aktivitas metakognisi yang dilakukan subjek bergaya kognitif reflektif yakni menentukan hasil yang mungkin dicapai serta men- gontrol kecermatan perhitungan. Pada tahap ini, subjek melakukan aktivitas metakognisi yang mirip dengan aktivitas pada masalah formal. Aktivitas metakognisi subjek bergaya kognitif impulsif hanya meliputi merencanakan saja tanpa melakukan pemantauan dan refleksi.

(4) Pada langkah interpretasi hasil dan merumuskan jawaban, subjek bergaya kognitif reflektif merumuskan jawaban melalui interpretasi hasil perhitungan didukung alasan yang tepat dengan memperhatikan pencapaian tujuan, sedangkan subjek bergaya kognitif impulsif melakukan aktivitas metakognisi berupa perencanaan, pemantauan maupun refleksi.

(5) Pada langkah evaluasi solusi, subjek bergaya kognitif reflektif melakukan aktivitas metakognisi memantau pencapaian tujuan dan refleksi untuk memperhatikan kekuatan dan kelemahan diri sendiri, sedangkan subjek bergaya kognitif impulsif evaluasi solusi melibatkan aktivitas metakognisi berupa pemantauan dan refleksi, yang umumnya merupakan respons atas pertanyaan peneliti.

\section{UCAPAN TERIMA KASIH}

Terima kasih diucapkan kepada Prof. Dr. Monang Sitorus M.Si., selaku Ketua Lembaga Penelitian dan Pengabdian pada Masyarakat Universitas HKBP Nommensen yang memberikan dana penelitian, dan kepada Ketua Program Studi Pendidikan Matematika yang memberikan kemudahan fasilitas selama melakukan penelitian. Terima kasih juga kepada pihak redaksi Jurnal Cakrawala Pendidikan Universitas Negeri Yogyakarta yang memberi kesempatan kepada penulis untuk mempublikasikan artikel ini.

\section{DAFTAR PUSTAKA}

Bell, A. W., Costello, J., dan Kuchemann, D. E. 1983. Review of Research in Mathematical Education. NFER-NELSON Publishing Company Ltd., Darville House

Chamot, A. U., Dale, M., O’Malley, J. M., Spanos, G. A. 1992. "Learning and Problem Solving Strategies of ESL Students." Bilingual Research Journal, 16: 3 \& 4 Summer/ Fall, $1-34$.

Cohors-Fresenborg, E., and Kaune, C., 2007. Modelling Classroom Discussion and 
Categorizing Discursive and Metacognitive Activities, In Proceeding of CERME $5,1180-1189$.

De Corte, E. 2003, Intervention Research: A Cara for Bridging the Theory-Practice Gap in Mathematics Education, Proceedings of the International Conference, The Mathematics Education into the 21st Century Project, Brno Czech Republic.

Flavell, J. H. 1979, Metacognition and Cognitive Monitoring, A New Area of Cognitive Developmental Inquiry, in Nelson, T. O. (Ed), 1992, Metacognition, Allyn and Bacon, Boston.

Gartman, S., and Freiberg, M., 1993, Metacognition and Mathematical Problem Solving: Helping Students to Ask The Right Questions, The Mathematics Educator, Volume 6 Number 1, 9 - 13

Kozhevnikov, Maria. 2007. Cognitive Style in the Context of Modern Psychology: Toward an Integrated Framework of Cognitve Style. Psychological Bulletin Volume 133 No. 3 pp. 464-481.American Psychological Assosiation.

McLoughlin, C., and Hollingworth, R. 2003. Exploring a Hidden Dimension of Online Quality: Matacognitive Skill Development, 16th ODLAA Biennial Forum Conference Proceedings. http://www.signadou,acu. edu.auDiunduh tanggal 12 Januari 2013.

Navarro, Jose I., Aguilar Manuel, dan Alcalde Concha. 1999. Relationship of Arithmetic Problem Solving and Reflective-impulsive Cognitive Styles in Third-Grade Students.
Psychological Report, Ohoi State University.

Panaoura, A., and Philippou, G., 2005, The Measurement of Young Pupils' Metacognitive Ability in Mathematics: The Case of SelfRepresentation and Self-Evaluation, www. ucy.ac.cy, Diunduh tanggal 12 November 2013.

Pearson Learning Group, Problem-Solving Experiences: Making Sense of Mathematics, Research Paper, www.pearsonlearning. com, diakses tanggal 2 Maret 2013.

Pencheva, E., \& Papazova, E. 2006. Cognitive Style And Values. Psychological Type and Culture - East \& West: A Multicultural Research Conference, http://typeandculture. org/Pages/C papers06/PenchevaCognitive Style.pdf diakses tanggal 4 Maret 2014.

Quiroga, A., Hernandez, J.M., Rupio, V., Shih, P.C., dan Santacreu, J. 2007. Influence of Impulsivity-Reflexivity when Testing Dynamic Spatial Ability: Sex and $g$ Differences. The Spanish Journal of Psychology 2007, Vol. 10, No. 2, 294-302.

Rozencwajk, Paulette dan Corroyer, Denis. 2005. Cognitive Processes in the ReflectiveImpulsive Cognitive Style. The Journal of Genetic Psychology, Vol.166 No. 4 Heldref Publication.

Warli, 2010. Profil Kreativitas Siswa yang Bergaya Kognitif Reflektif dan Siswa yang Bergaya Kognitif Impulsif dalam Memecahkan Masalah Geometri. Disertasi PPS Unesa Surabaya. 